IRA-International Journal of Education \& Multidisciplinary Studies

ISSN 2455-2526; Vol.04, Issue 01 (2016)

Institute of Research Advances

http://research-advances.org/index.php/IJEMS

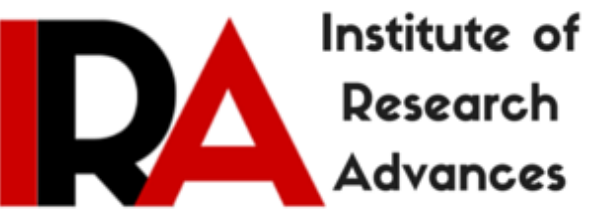

\title{
Education and its Impact on Social Change in Punjab
}

\author{
${ }^{1}$ Dr. Maninder S. Sarkaria \\ Deputy State Project Director, \\ RMSA, Punjab, India. \\ ${ }^{2}$ Shiwani \\ Assistant Professor, S.G.A.D. College, \\ Khadur Sahib, Tarn -Taran (Punjab), India.
}

DOI: $\underline{\text { http://dx.doi.org/10.21013/jems.v4.n1.p11 }}$

\section{How to cite this paper:}

Sarkaria, M., \& Sharma, S. (2016). Education and its Impact on Social Change in Punjab. IRA International Journal of Education and Multidisciplinary Studies (ISSN 2455-2526), 4(1). doi:http://dx.doi.org/10.21013/jems.v4.n1.p11

(c) Institute of Research Advances

\section{(co) EY-NG}

This works is licensed under a Creative Commons Attribution-Non Commercial 4.0 International License subject to proper citation to the publication source of the work.

Disclaimer: The scholarly papers as reviewed and published by the Institute of Research Advances (IRA) are the views and opinions of their respective authors and are not the views or opinions of the IRA. The IRA disclaims of any harm or loss caused due to the published content to any party. 


\begin{abstract}
Significance of education in the development process has been well recognized by the educational planners, economists and development planners the world over. Based on empirical evidences of connection between education and socio-economic development, this paper posits that education is instrumental in the socio-economic development. Specifically, this paper examines the impact of educational progress on fertility rate, population growth rate, child/infant mortality rate, life expectancy, gender disparity, poverty of the state. The analysis is based on information of the entire state on various variables such as literacy rate, enrolment, per capita income, fertility rate, population growth rate, incidence of poverty, etc. gathered from the secondary sources from 1966 onward. To sort out the strength and direction of relationships between education and various components of social developments, data have been analyzed by employing simple regression models.

The findings show that female education at all levels has been found to be highly significant in lowering infant mortality. Male and female life expectancy at birth and at specific ages have been found to be positively related with enrolment at different educational levels.

In line with the research conducted in different parts of the world, this study also confirms that increased female education at all the stages (i.e. primary, elementary, secondary and for all education levels put together) consistently lowers fertility rates.

Our regression results show positive relationship between the progress of education at different stages and the gender disparity in infant mortality. Further, The poverty reduction effect of education has been confirmed from the inverse relationship of the educational progress at different stages of schooling with the incidence of deprivation (poverty).
\end{abstract}

Keywords: Education, Fertility, Population Growth, Poverty, Gender Disparity

\title{
Introduction
}

Since education is widely referred to as prime mover of growth and development of economy and widely described as an agent of economic and social transformation, both, the economists and the educationists have shown interests to study the relationship between socio-economic development and education. It has been observed that, by and large, developed countries perform better on educational indicators and enjoy better social status. Education is now recognized as a basic human right as it is closely linked to virtually all dimensions of development - human, economic, and social. It is also a key factor in improving governance. Investment in education supports a much broader agenda including health, nutrition, the values of the environment and community participation, and as such results in multiplicity of benefits.

Basic education gives people access to information through both print and electronic media, equips them to cope better with work and family responsibilities, and changes the perception they have of themselves. It enhances their self-confidence to participate in community affairs and influence political issues. Basic education is the key with which individuals can unlock the full range of their talents and realize their creative potential. Basic education also empowers entire nations in ways more than one: Educated citizens and workers have the skills to make democratic institutions function effectively, to meet the demands for a more sophisticated workforce, to work for a cleaner environment, and to meet their obligations as parents and citizens ${ }^{1}$.

\footnotetext{
${ }^{1}$ United Nations Educational, Scientific, and Cultural Organization. 1997. Adult Education in a Polarizing World. Paris. Accessed on 5-6-2011 through http://www.adb.org/Documents/Policies/Education/educ0300.asp? $\mathrm{p}=$ educ
} 
The benefits of education are not limited to economic paybacks only ${ }^{2}$ and the social development is not the outcome of education only. Apart from education, social development is affected by economic growth, natural endowment, etc. This paper investigates economic and non-economic benefits of education using secondary data at the macro level. As social development is not the result of education alone we have included various control variables in the regression models which may affect the social development. Further, as women education has been shown to play pivotal role in the social and economic development, a section of the paper has been devoted to describe the role of women education in the process of development. Specifically, this paper examines the impact of educational progress women education on fertility rate and IMR and of overall education on sex-ratio, population growth rate, life expectancy, gender disparity, poverty in Punjab.

\section{Education and Social Development}

It is widely acknowledged that apart from improving economy at all levels of a nation, education creates better citizens and helps to upgrade the general standard of living in a society. Therefore, positive social change is associated with the progress of education. Evidences in favour of education as an agent of change in many developing countries, including India, have been persuading planners for making heavy investment in it (Olaniyan and Okemakinde, 2008).

The significance of education for the prosperity of mankind can never be overlooked. It plays progressive role in every sphere - be it mental, moral, economic, social, cultural, or political. Its contribution has been acknowledged and applauded by all societies in all times. For instance, four decades ago, the Education Commission $(1966$, p.3) in India realized: 'The destiny of India is now being shaped in her class rooms.' And for that purpose a higher allocation of 5-6 per cent of GNP on education has been reiterated by one and all incessantly. Yet it could not become a practical reality even after six decades of Independence. The President of India, Dr. A. P. J. Abdul Kalam, while addressing the nation on the eve of the $58^{\text {th }}$ Independence Day, strongly advocated the increase in the expenditure on education to 6-7 per cent of the Gross Domestic Product (GDP) from the present 4 per cent to turn India into a "prosperous, happy and strong nation."

Expenditure on education is now thought of as an investment ${ }^{3}$ in mankind ${ }^{4}$. Investment in education is termed as 'Human Wealth' and 'Human Capital'. Educated people of any country play key role in its social development. The physical capital of any economy would lay waste devoid of human capital. Consume bundle of wealth to buy the most sophisticated technology or machinery - but of no use without trained and skilled workers to work upon it. Develop a highly efficient and effective system to achieve the goals - but won't work as desired if not manned by educated personnel to run it. Education and development of a country are inter-dependant. One cannot exist without the other (Natarajan, 1990, Vaizey, 1962).

Brar (2002) has examined the relationship among education, health and economic growth in Punjab and has also compared its performance on educational, health and economic indicators with those of Kerala, which is the top performing state of India on education front. For the study, he culled out the required data from different sources for the years 1971 onwards. His analysis shows that Punjab has gained noticeable economic prosperity in comparisons to the other states of India, primarily on account of its success on agricultural front, a well-developed industrial sector in a few urban pockets and foreign remittances by NRIs. But it has not progressed proportionately on social front.

\footnotetext{
${ }^{2}$ The study by Haveman and Wolfe (1984) has enlisted as many as 20 different non-wage benefits of additional education that are not normally incorporated in the models for computing rate of return on investment in education.

${ }^{3}$ Investment is precisely defined as "current allocation of resources for the purposes of expanding output at some future date". Any activity that entails a cost in the current period and raises productivity in the future can be analyzed within the framework of investment theory (Becker, 1975).

${ }^{4}$ The role of education in development was duly acknowledged even many centuries ago; for example, Plato regarded education to be sine qua non for economic health of the society and advocated investment of community's wealth in education (Atal, 2007:23).
} 
Gupta (1990) examined, amongst other things, socio-economic determinants of child mortality in rural Punjab. For the purpose of her study she collected the required data by surveying eleven villages from Ludhiana district of Punjab. Her study shows that education improves mother's child-care practices, her domestic management of ill-health, efforts at preventive care and use of modern medical services helping ultimately to reduce child mortality.

Mathur and Mamgain (2002) have examined the impact of technical education (TE) and general education (GE) on the socio-economic development of India. The socio-economic development in their study consists of four dimensions viz. Per capita state income (PCI), non-agricultural level of development (NONAG), reduction in the incidence of poverty (POV), and reduction in the incidence of unemployment (UNEMP).

Both, the TE as well as the GE have shown strong positive relationships with PCI and NONAG. The impact of TE on PCI and NONAG is much stronger than that of GE. The correlations of TE as well as that of GE with POV are found to be strong and negative. However, Contrary to expectations, both, the TE and the GE, by and large, are found to be associated positively with UNEMP (but at low level of significance). However, they attribute this unexpected association to, inter alia, inadequate expansion of demand in the productive sectors of the economy.

Tilak (2001) has reviewed the track of educational development in Asian countries in the context of changing socio-economic and political environment. He has shown that expansion of education is positively and highly correlated with socio-economic development. On the basis of his comprehensive review of empirical researches undertaken in Asian countries, he has provided the following tentative generalizations regarding the impact of education on development:

Education, inter alia, contributes significantly:

-to expedite economic growth and the returns to education are not less than those which come from investment in physical capital; to enhance the productivity of work force; in reducing poverty; in improving income distribution; in reducing fertility rate, population growth, child/infant mortality rate etc. and in improving other basic needs.

Rao (2004) sorted out the impact of the literacy rate of male, female, and total population on the infant mortality rate in India. His regression results showed that all the literacy rates had negative impact on infant mortality rate, which implied that infant mortality rate declined with increase in education levels. However, female literacy was found to be most crucial in declining infant mortality rate.

Appiah and McMahon (2002) comprehensively estimated impacts of education on various social indicators in Africa. Education was found to improve infant mortality, increase longevity, strengthen civic institutions and their democratisation, increase political stability, and increase investment in physical capital, and all of these had favourable delayed impact on the economic growth process.

To sum up, overview of literature on relations between educational progress and social development reveals that education is a significant factor in the course of social development of a country.

\section{The Objectives}

Major objective of this paper is to examine the impact of education on the social development of Punjab. The specific objectives of this study are listed as below:

1. To examine the impact of educational progress of women education on fertility rate;

2. To analyze the effect of growth in education on the population growth rate;

3. To study the relationship between women education and child/infant mortality rate;

4. To explore the relationship between education and life expectancy;

5. To examine the impact of education on gender disparity; 


\section{Data Base and Methodology}

\section{The Sample and Period of the Study}

To fulfill the objectives of this study, we required information of the entire state on various variables such as literacy rate, enrolment, fertility rate, population growth rate, etc. Data on these variables are available from the secondary sources. We have sought to collect data from 1966 onward as the present Punjab came into being in 1966 on linguistic basis.

\section{Data Collection}

Data on various indicators of education and social development for the state of Punjab have been collected from secondary sources such as annual budget, Statistical Abstract of Punjab, Census of India, NSSO, etc.

\section{Data Analysis}

To sort out the strength and direction of relationships between education and various components of social developments, data have been analyzed by employing simple regression models. Data have been analyzed by using PASW (Predictive Analytics Software formerly SPSS Software) version 18.0 on computer.

\section{Variables and Hypotheses}

Indicators of Educational Growth (Variables and their data source is given in Appendix-I)

Enrolment Ratios: The enrolment ratio is the most widely used indicator for the assessment of educational coverage. It provides the proportion of children enrolled in the schools to the total agespecific population. For the purpose of this study we have computed level-wise enrolment ratios. The level-wise enrolment ratio provides the coverage of children by a specific level of education, e.g. primary or secondary. There are two types of level-wise enrolment ratios viz. the Gross Enrolment Ratio (GER) and the Net Enrolment ratio (NER). The net enrolment ratio is considered more appropriate as it is age-specific. Since age has been taken into account in the numerator, NER never exceeds 100 percent. For planning purposes, NER is considered more reliable indicator than GER, as it is age specific (Zaidi, 1997). NER is computed as under:

For the primary level of education (i.e. grades 1-5)

Total enrolment in grades 1-5 aged 6-11 in the year ' $\mathrm{t}$ '

Net Enrolment Ratio $\left(\mathrm{NER}_{1}\right)=$

X 100

Total population aged 6-11 in the year ' $\mathrm{t}$ '

Further, data on enrolments could be found only for the years 1981, 1991 and 2000 when this study was conducted. So we formed time series for NERs by using appropriate statistical technique.

Infant Mortality Rate (IMR): IMR shows the number of children dying, before celebrating their first birthday, per thousand live births. A number of researchers have employed this variable to show the social outcome of education (Appiah and Mcmahon 2002, Brar 2002). A negative association is expected between education of females and infant mortality rate. However, education of mother may also have unhealthy effects on child's health. Many researchers have revealed that educated women tend to breastfeed for a shorter duration than others ${ }^{5}$

Fertility Rate (TFR): Total fertility rate indicates live births per thousand women (15-49 years). Female education is expected to lower fertility rate because more educated females are better able to comprehend and utilize contraception techniques. Further, the number of childbearing years is diminished as females stay in school longer. Furthermore, educated women would like to have fewer children so that they can enter job markets.

\footnotetext{
${ }^{5}$ See e.g., United Nations 1995
} 
Life Expectancy (LEXP): Life expectancy is an index of health of population. Expansion of education is expected to improve life expectancy. Those with more education are expected to live longer because education enables them to acquire knowledge about nutrition and other health improving techniques. In this study we have worked out the relationships of education with life expectancy of males and females at birth as well as at the age of 60 .

Gender Disparity (GNDS): We have taken three variables to represent gender disparity. Gender disparity in infant mortality (GNDSIMR) is computed by dividing female infant mortality by male infant mortality. The other two variables taken to represent gender disparity are sex ratio for ages (GNDSSRALAG) and sex ratio of children of 0-6 years (GNDSSR (G-6 ). Sex ratio is defined as number of females per 1,000 males. The progress of education is expected to correct all type of gender bias.

Population Growth (POP, POPGR): We have employed two indicators of population growth in our study - Population increase in absolute figures (POP) and annual growth rates of population (POPGR). The effects of education on net population growth rates follow directly from infant mortality, longevity and fertility effects (Appiah and McMahon 2002). In other words, educational growth improves health, increases longevity, reduces infant mortality and fertility rate. States with high female literacy levels usually have low rates of population growth: Kerala, where female literacy is the highest in India, has reduced its annual population growth rate to 1.3 per cent by 1991 (minimum in India). Crude Birth Rate (CBR) and United Death Rate (CDR), Infant Mortality Ratio (IMR) are also minimum in Kerala ${ }^{6}$.

The sources of data for various variables used in this study are contained in Appendix-I.

\section{Models}

In order to sort out the effects of educational growth on social development, the following linear models have been employed:

\section{For Effect of Education on Infant Mortality}

Following regression equation has been used to sort out the impact of education on Infant mortality (abbreviation of variables and their definition is contained in Appendix I):

$$
\begin{aligned}
& \mathrm{IMR}=\beta_{0}+\beta_{1}\left(\mathrm{NER}_{1 \mathrm{~F}}\right)+\mathrm{e} \\
& \mathrm{IMR}=\beta_{0}+\beta_{1}\left(\left(\mathrm{NER}_{2 \mathrm{~F}}\right)+\mathrm{e}\right. \\
& \mathrm{IMR}=\beta_{0}+\beta_{1}\left(\mathrm{NER}_{3 \mathrm{~F}}\right)+\mathrm{e} \\
& \mathrm{IMR}=\beta_{0}+\beta_{1}\left(\mathrm{NER}_{4 \mathrm{~F}}\right)+\mathrm{e} \\
& \mathrm{IMR}=\beta_{0}+\beta_{1}(\mathrm{PCI})+\mathrm{e}
\end{aligned}
$$

Regression equation with PCI has been computed to examine the effect of per capita income on IMR.

\section{Effect of Education on Life Expectancy}

$$
\begin{aligned}
& \text { LEXP }=\beta_{0}+\beta_{1}(\text { IMR })+e \\
& \text { LEXP }=\beta_{0}+\beta_{1}(\text { NERT })+e \\
& \text { LEXP }=\beta_{0}+\beta_{1}(\text { PCI })+e
\end{aligned}
$$

Regression equations with IMR and PCI have been computed to examine their effect on LEXP.

\section{For Effect of Education on Fertility Rate}

$$
\begin{aligned}
& \mathrm{TFR}=\beta_{0}+\beta_{1}\left(\mathrm{NER}_{1 \mathrm{~F}}\right)+\mathrm{e} \\
& \mathrm{TFR}=\beta_{0}+\beta_{1}\left(\mathrm{NER}_{2 \mathrm{~F}}\right)+\mathrm{e} \\
& \mathrm{TFR}=\beta_{0}+\beta_{1}\left(\mathrm{NER}_{3 \mathrm{~F}}\right)+\mathrm{e} \\
& \mathrm{TFR}=\beta_{0}+\beta_{1}\left(\mathrm{NER}_{4 \mathrm{~F}}\right)+\mathrm{e}
\end{aligned}
$$

\footnotetext{
${ }^{6}$ News Letter-43, Oct.-Dec. 1993, Publication Number 77, Population Education Cell, S.I.S.E., SCERT, Punjab, Chandigarh, p.1 and also see Ramachandran, Singh, Kapoor and Lamba (2000), Population Growth-Trends, Projections, Challenges and Opportunities, (Working Paper No. 2/2000-PC). Planning Commission. Retrieved on 18-7-2011 from http://planningcommission.nic.in/reports/wrkpapers/wp_hwpaper.pdf
} 


\section{For Effect of Education on Gender Disparity}

$$
\begin{aligned}
& \text { GNDSIMR }=\beta_{0}+\beta_{1}\left(\mathrm{NER}_{1 \mathrm{~T}}\right)+\mathrm{e} \\
& \text { GNDSIMR }=\beta_{0}+\beta_{1}\left(\mathrm{NER}_{2 \mathrm{~T}}\right)+\mathrm{e} \\
& \text { GNDSIMR }=\beta_{0}+\beta_{1}\left(\mathrm{NER}_{3 \mathrm{~T}}\right)+\mathrm{e} \\
& \text { GNDSIMR }=\beta_{0}+\beta_{1}\left(\mathrm{NER}_{4 \mathrm{~T}}\right)+\mathrm{e} \\
& \text { GNDSSRALAG }=\beta_{0}+\beta_{1}\left(\mathrm{NER}_{1 \mathrm{~T}}\right)+\mathrm{e} \\
& \text { GNDSSRALAG }=\beta_{0}+\beta_{1}\left(\mathrm{NER}_{2 \mathrm{~T}}\right)+\mathrm{e} \\
& \text { GNDSSRALAG }=\beta_{0}+\beta_{1}\left(\mathrm{NER}_{3 \mathrm{~T}}\right)+\mathrm{e} \\
& \text { GNDSSRALAG }=\beta_{0}+\beta_{1}\left(\mathrm{NER}_{4 \mathrm{~T}}\right)+\mathrm{e} \\
& \text { GNDSSR }_{0-6}=\beta_{0}+\beta_{1}\left(\mathrm{NER}_{1 \mathrm{~T}}\right)+\mathrm{e} \\
& \text { GNDSSR }_{0-6}=\beta_{0}+\beta_{1}\left(\mathrm{NER}_{2 \mathrm{~T}}\right)+\mathrm{e} \\
& \operatorname{GNDSSR}_{0-6}=\beta_{0}+\beta_{1}\left(\mathrm{NER}_{3 \mathrm{~T}}\right)+\mathrm{e} \\
& \operatorname{GNDSSR}_{0-6}=\beta_{0}+\beta_{1}\left(\mathrm{NER}_{4 \mathrm{~T}}\right)+\mathrm{e}
\end{aligned}
$$

\section{For Effect of Education on Population Growth}

$$
\begin{aligned}
& \mathrm{POP}=\beta_{0}+\beta_{1}\left(\mathrm{NER}_{1 \mathrm{~T}}\right)+\mathrm{e} \\
& \mathrm{POP}=\beta_{0}+\beta_{1}\left(\mathrm{NER}_{2 \mathrm{~T}}\right)+\mathrm{e} \\
& \mathrm{POP}=\beta_{0}+\beta_{1}\left(\mathrm{NER}_{3 \mathrm{~T}}\right)+\mathrm{e} \\
& \mathrm{POP}=\beta_{0}+\beta_{1}\left(\mathrm{NER}_{4 \mathrm{~T}}\right)+\mathrm{e} \\
& \mathrm{POPGR}=\beta_{0}+\beta_{1}\left(\mathrm{NER}_{1 \mathrm{~T}}\right)+\mathrm{e} \\
& \mathrm{POPGR}=\beta_{0}+\beta_{1}\left(\mathrm{NER}_{2 \mathrm{~T}}\right)+\mathrm{e} \\
& \mathrm{POPGR}=\beta_{0}+\beta_{1}\left(\mathrm{NER}_{3 \mathrm{~T}}\right)+\mathrm{e} \\
& \mathrm{POPGR}=\beta_{0}+\beta_{1}\left(\mathrm{NER}_{4 \mathrm{~T}}\right)+\mathrm{e}
\end{aligned}
$$

Such models have been used by Appiah and McMahan (2002) and Mathur and Mamgain (2002).

\section{Findings}

The results of least squares estimation of regression equations, which seeks to explain the effects of education in terms of various components of social development are contained in Tables 1.1 to 1.5

\section{Effect of Education on Infant Mortality}

The regression results contained in Table 1.1 show that education of females at primary, elementary and secondary levels is inversely related to infant mortality rate. Overall female education (i.e. for the age group 6-18) is also showing the same relation with IMR. In other words, female education at all levels is highly significant in lowering infant mortality. This shows that educated mothers remain aware of various health programmes of the State (e.g. National Immunization Programme) and hence, are expected to act positively to do away with various causes of infant mortality. As expected, per capita income is negatively associated with infant mortality. Put differently, higher per capita income helps in lowering infant mortality. All the relations are statistically significant at 0.01 level.

Table 1.1

Regression Coefficients (Standardized) Educational Growth and Infant Mortality Rate (Dependent Variable: IMR)

\begin{tabular}{|l|l|l|l|l|}
\hline Determinants & Standardised $\beta$ & t-value & Adjusted $\mathrm{r}^{2}$ & F-value \\
\hline NER $_{1 \mathrm{~F}}$ & $-0.864^{*}$ & -7.287 & 0.733 & $53.095^{*}$ \\
\hline $\mathrm{NER}_{2 \mathrm{~F}}$ & $-0.868^{*}$ & -7.408 & 0.739 & $54.871^{*}$ \\
\hline NER $_{3 \mathrm{~F}}$ & $-0.870^{*}$ & -7.473 & 0.743 & $55.850^{*}$ \\
\hline NER $_{4 \mathrm{~F}}$ & $-0.825^{*}$ & -6.199 & 0.663 & $38.422^{*}$ \\
\hline PCI & $-0.899^{*}$ & -8.713 & 0.798 & $75.924^{*}$ \\
\hline
\end{tabular}

Number of Observations: $20 \quad$ *: Significant at 1 per cent level. 


\section{Effect of Education on Life Expectancy}

Secondary education enrolment rate is considered a key determinant of life expectancy (Appiah and McMahon, 2002). Table 1.2 shows that male and female life expectancy at birth and at specific ages is consistently positively related with enrolment at different educational levels. Enrolments at the elementary and the secondary stages are statistically significant at 0.01 level and also for the combined enrolments for the age groups of 6-18 years. This finding is consistent with studies by Cochrane et al., 1980 and Grossman and Kaestner, 1997 who after controlling for income find that those with more education live longer. The study of Frank and Mustard (1994) also reports that education enables individuals to gain knowledge about nutrition that lowers mortality rates and increases life expectancy.

Table 1.2

Regression Coefficients (Standardized) for Educational Growth and Life Expectancy (Dependent Variable: LEXP)

\begin{tabular}{|c|c|c|c|c|c|c|c|c|}
\hline \multirow{2}{*}{$\begin{array}{l}\text { Determinan } \\
\text { ts }\end{array}$} & \multicolumn{4}{|c|}{ Dependent Variable: LEXP $_{0 \mathrm{M}}$} & \multicolumn{4}{|c|}{ Dependent Variable: LEXP $_{0 \mathrm{~F}}$} \\
\hline & $\begin{array}{l}\text { Standardised } \\
\beta\end{array}$ & t-value & $\begin{array}{l}\text { Adjusted } \\
\mathrm{r}^{2}\end{array}$ & F-value & $\begin{array}{l}\text { Standardised } \\
\beta\end{array}$ & t-value & $\begin{array}{l}\text { Adjusted } \\
\mathrm{r}^{2}\end{array}$ & $\begin{array}{l}\text { F- } \\
\text { value }\end{array}$ \\
\hline $\mathrm{NER}_{1 \mathrm{~T}}$ & $0.607 * *$ & 2.754 & 0.320 & $7.58 * *$ & $0.560 * *$ & 2.436 & 0.261 & $\begin{array}{l}\text { 5.94* } \\
*\end{array}$ \\
\hline $\mathrm{NER}_{2 \mathrm{~T}}$ & $0.941^{*}$ & 9.987 & 0.876 & $99.73 *$ & $0.939 *$ & 9.885 & 0.874 & $\begin{array}{l}97.72 \\
*\end{array}$ \\
\hline $\mathrm{NER}_{3 \mathrm{~T}}$ & $0.938 *$ & 9.726 & 0.870 & $94.59 *$ & $0.931 *$ & 9.169 & 0.856 & $\begin{array}{l}83.97 \\
*\end{array}$ \\
\hline $\mathrm{NER}_{4 \mathrm{~T}}$ & $0.937 *$ & 9.667 & 0.868 & $93.45^{*}$ & $0.932 *$ & 9.251 & 0.858 & $\begin{array}{l}85.58 \\
*\end{array}$ \\
\hline IMR & $-0.916^{*}$ & -8.248 & 0.827 & $68.03^{*}$ & $-0.907^{*}$ & -7.746 & 0.808 & $\begin{array}{l}60.01 \\
*\end{array}$ \\
\hline PCI & $0.944 *$ & 10.298 & 0.882 & $106.56^{*}$ & $0.932 *$ & 9.284 & 0.859 & $\begin{array}{l}86.19 \\
*\end{array}$ \\
\hline $\mathrm{PCI}_{\mathrm{lg}}$ & $0.946^{*}$ & 10.529 & 0.887 & $110.86^{*}$ & $0.938^{*}$ & 9.780 & 0.871 & $\begin{array}{l}95.65 \\
* \\
*\end{array}$ \\
\hline \multirow{2}{*}{$\begin{array}{l}\text { Determinan } \\
\text { ts }\end{array}$} & \multicolumn{4}{|c|}{ Dependent Variable: LEXP ${ }_{60 \mathrm{M}}$} & \multicolumn{4}{|c|}{ Dependent Variable: LEXP $_{60 \mathrm{~F}}$} \\
\hline & $\begin{array}{l}\text { Standardised } \\
\beta\end{array}$ & t-value & $\begin{array}{l}\text { Adjusted } \\
\mathrm{r}^{2}\end{array}$ & F-value & $\begin{array}{l}\text { Standardised } \\
\beta\end{array}$ & t-value & $\begin{array}{l}\text { Adjusted } \\
\mathrm{r}^{2}\end{array}$ & $\begin{array}{l}\text { F- } \\
\text { value }\end{array}$ \\
\hline $\mathrm{NER}_{1 \mathrm{~T}}$ & $0.631 *$ & 2.229 & 0.351 & $8.58 *$ & 0.240 & 0.890 & 0.015 & 0.80 \\
\hline $\mathrm{NER}_{2 \mathrm{~T}}$ & $0.937 *$ & 9.697 & 0.869 & $94.03^{*}$ & $0.791 *$ & 4.463 & 0.597 & $\begin{array}{l}21.74 \\
*\end{array}$ \\
\hline $\mathrm{NER}_{3 \mathrm{~T}}$ & $0.938 *$ & 9.729 & 0.870 & $94.65 *$ & 0.754* & 4.136 & 0.535 & $\begin{array}{l}17.11 \\
*\end{array}$ \\
\hline $\mathrm{NER}_{4 \mathrm{~T}}$ & $0.936^{*}$ & 9.584 & 0.866 & $91.85^{*}$ & $0.764 *$ & 4.271 & 0.552 & $\begin{array}{l}18.24 \\
*\end{array}$ \\
\hline IMR & $-0.918^{*}$ & -8.337 & 0.830 & $69.51 *$ & $-0.721^{*}$ & -3.746 & 0.482 & $\begin{array}{l}14.04 \\
*\end{array}$ \\
\hline PCI & $0.946^{*}$ & 10.561 & 0.888 & 111.54 & $0.732 *$ & 3.878 & 0.501 & $\begin{array}{l}15.04 \\
*\end{array}$ \\
\hline $\mathrm{PCI}_{\mathrm{lg}}$ & $0.946^{*}$ & 10.571 & 0.888 & $111.75^{*}$ & 0.757* & 4.174 & 0.540 & $\begin{array}{l}17.42 \\
*\end{array}$ \\
\hline
\end{tabular}

Number of Observations: 15.

*: Significant at 1 per cent level. **: Significant at 1 per cent level.

As expected, LEXP and IMR are showing negative association and are statistically significant in all regression equations. Infant mortality is important to longevity. Education influences life expectancy mostly through this channel. In other words, education reduces infant mortality that in turn influences longevity favourably. 


\section{Effect of Education on Fertility Rate}

Table 135 contains the regression coefficients for educational progress of female and total fertility rate on the basis of 17 years time series data. The indicators of enrolment growth for different age groups and education levels are inversely related with fertility rates. All the relations are statistically significant at 0.01 level.

It shows that increased female education at all the stages (i.e. primary, elementary, secondary and for all education levels put together) consistently lowers fertility rates. Research conducted in different parts of the world over the last 25 years shows that women with more education make a better transition to adulthood and have smaller, healthier families. They usually have their first sexual experience later, marry later, prefer smaller families and are likely to use contraceptives as compared to their less educated counterparts (Sarkaria, 2002). Presumably, more educated females can better comprehend and utilize contraception techniques. Further, the number of childbearing years is diminished as females stay in schools longer and furthermore education provides economic incentives to women to have fewer children so that they can enter job markets (Cochrane, 1979; Moore et al. 1993; Schultz, 1993)

Table 1.3

Regression Coefficients (Standardized) for Female Education and Fertility Rate (Dependent Variable: TFR)

\begin{tabular}{|l|l|l|l|l|}
\hline Determinants & Standardised $\beta$ & t- value & Adjusted $\mathrm{r}^{2}$ & F- value \\
\hline $\mathrm{NER}_{1 \mathrm{~F}}$ & $-0.963^{*}$ & -13.922 & 0.923 & $193.827^{*}$ \\
\hline $\mathrm{NER}_{2 \mathrm{~F}}$ & $-0.968^{*}$ & -14.889 & 0.932 & $221.694^{*}$ \\
\hline $\mathrm{NER}_{3 \mathrm{~F}}$ & $-0.961^{*}$ & -13.421 & 0.918 & $180.118^{*}$ \\
\hline $\mathrm{NER}_{4 \mathrm{~F}}$ & $-0.937^{*}$ & -10.345 & 0.869 & $107.010^{*}$ \\
\hline
\end{tabular}

Number of Observations: 17

*: Significant at 1 per cent level.

\section{Effect of Education on Gender Disparity}

Our regression results show positive relationships between the progress of education at different stages and the gender disparity in infant mortality. Despite improvement in literacy, expansion in outreach of health care services and rise in overall living standards, the sex composition of infant mortality trends in Punjab indicates that greater vulnerability of the girl child. This implies preponderance of social, cultural and economic rather than health, education and medical factors. This fact is endorsed by the fertility data of Census 2001, which reveals that the more educated the mother; the more the chances that she will resort to female foeticide. In Punjab, the girl-boy ratio is $845: 1000$ in case of illiterate mothers and 745:1000 when the mothers are literate (Jerath 2005).

Table 1.4

Regression Coefficients (Standardized) for Gender Disparity

\begin{tabular}{|l|l|l|l|l|}
\hline \multirow{2}{*}{ Determinants } & \multicolumn{4}{|l|}{ Dependent Variable: GNDSIMR } \\
\cline { 2 - 5 } & Standardised $\beta$ & t-value & Adjusted $\mathrm{r}^{2}$ & F-value \\
\hline $\mathrm{NER}_{1 \mathrm{~T}}$ & 0.424 & 1.986 & 0.134 & 3.945 \\
\hline $\mathrm{NER}_{2 \mathrm{~T}}$ & $0.525^{* *}$ & 2.616 & 0.235 & $6.841^{* *}$ \\
\hline $\mathrm{NER}_{3 \mathrm{~T}}$ & $0.529^{* *}$ & 2.645 & 0.240 & $6.995^{* *}$ \\
\hline NER $_{4 \mathrm{~T}}$ & $0.528^{* *}$ & 2.637 & 0.239 & $6.955^{* *}$ \\
\hline \multirow{2}{*}{ Determinants } & Dependent Variable: GNDSSRALAG & \multicolumn{1}{|l|}{} \\
\cline { 2 - 5 } & Standardised $\beta$ & t-value & Adjusted $\mathrm{r}^{2}$ & F-value \\
\hline $\mathrm{NER}_{1 \mathrm{~T}}$ & $-0.926^{*}$ & -10.438 & 0.850 & $108.952^{*}$ \\
\hline $\mathrm{NER}_{2 \mathrm{~T}}$ & -0.414 & -1.931 & 0.126 & 3.728 \\
\hline NER $_{3 \mathrm{~T}}$ & $-0.579^{*}$ & -3.010 & 0.298 & $9.057^{*}$ \\
\hline NER $_{4 \mathrm{~T}}$ & $-0.560^{* *}$ & -2.867 & 0.275 & $8.217^{* *}$ \\
\hline Determinants & Dependent Variable: GNDSSR & \\
\hline
\end{tabular}




\begin{tabular}{|l|l|l|l|l|}
\hline & Standardised $\beta$ & t-value & Adjusted $\mathrm{r}^{2}$ & F-value \\
\hline $\mathrm{NER}_{1 \mathrm{~T}}$ & $-0.965^{*}$ & -15.639 & 0.928 & $244.579^{*}$ \\
\hline $\mathrm{NER}_{2 \mathrm{~T}}$ & $-0.880^{*}$ & -7.873 & 0.762 & $61.978^{*}$ \\
\hline $\mathrm{NER}_{3 \mathrm{~T}}$ & $-0.954^{*}$ & -13.504 & 0.905 & $182.348^{*}$ \\
\hline $\mathrm{NER}_{4 \mathrm{~T}}$ & $-0.949^{*}$ & -12.501 & 0.891 & $156.282^{*}$ \\
\hline
\end{tabular}

Number of Observations: 20

*: Significant at 1 per cent level. **: Significant at 5 per cent level.

The relationships of sex ratios (for total as well as for child population) with the expansion of education at different stages are negative and, by and large, statistically significant. The sex composition of the population is an important indicator of social development. But, in Punjab, the sex ratios show declining trend for total as well as the child population (0-6 age group). This gloomy scenario may broadly be explained in terms of variations in sex composition of births and sex differences in mortality. Further, this unfavorable situation can also be attributed to socio-economic and cultural aspects of the society. The overall preference for the male child clubbed with the failure of the law enforcing machinery in banning the sex determination tests which are available at affordable prices in Punjab has deteriorated this imbalance beyond doubt.

Regretfully, in most of the under-developed and developing countries, culture also gives a back seat to women. Indian culture gives preference to boys over girls with respect to various matters. Sons are preferred to girls; for they are supposed to support their parents, when they are aged. This cultural preference along with the prevalence of dowry causes subtle neglect of female infants and condition is much more pathetic in poor families. Consequently, parents are least bothered about baby-girls in matters of proper nutrition or vaccination. As a result, death rate for younger girls is high and eventually results in decrease of women population. Sex-ratio change in India is due to bias against women and is ultimately leading to an adverse trend through the century-it moved downward from 972 in 1901 to 927 in 1991, the lowest figure in the century; which moved up to 933 \& 940 in 2001 \& 2011 respectively and that of Punjab is much lower 882 in 1991, 876 in 2001 and 893 in 2011. India's adverse sex-ratio seems to indicate that mortality was unusually high for Indian woman. Women are still deprived of even the most vital health services and medical care. Only about one third of Indian births are attended by trained medical personnel. This may be taken as one of the many factors, which can be held responsible for India's high infant and maternal mortality rates. Nobel laureate Amartya Sen, rightly argues that low female-male ratio is due to absence of food and health care of women. This critical ratio can further deteriorate as parents can detect in advance the sex of their babies and avoid female births by aborting female fetus.

The low status of women is also evident from certain other attitudes of people. In most Indian families, women are not consulted in financial decisions, kinship relationships and in the selection of spouse. They are not given authority to decide the size of their family. The scenario is not different in Punjab.

It is obvious from the above discussion that women have very poor status in terms of almost every aspect. The analysis revealed that women in India suffer from an adverse sex-ratio, poor health-care, and wide spread illiteracy. They are culturally and socially neglected. Their economic role remains unrecognized.

\subsubsection{Education and Population Growth}

We have computed regression equations of educational progress with two indicators of population growth viz. with population increase in absolute figures and with annual growth rates. The former is positive and statistically significant at 0.01 level. In other words, population has increased with educational progress. This is not unexpected as the effects of education on population growth follow directly from infant mortality, longevity, and fertility effects. As we have seen in our preceding analyses, educational growth improves health, increases longevity, reduces infant mortality and fertility rate, hence, the net population growth in absolute numbers may tend to increase with 
educational progress as is seen in our analysis. However, the rate of population growth has slowed down with educational progress.

Table 1.5

Regression Coefficients (Standardized) for Population Growth

\begin{tabular}{|l|l|l|l|l|}
\hline \multirow{2}{*}{ Determinants } & \multicolumn{4}{|l|}{ Dependent Variable: POP } \\
\cline { 2 - 5 } & Standardised $\beta$ & t-value & Adjusted $\mathrm{r}^{2}$ & F-value \\
\hline $\mathrm{NER}_{1 \mathrm{~T}}$ & $0.896^{*}$ & 8.564 & 0.792 & $73.343^{*}$ \\
\hline $\mathrm{NER}_{2 \mathrm{~T}}$ & $0.954^{*}$ & 13.567 & 0.906 & $184.063^{*}$ \\
\hline $\mathrm{NER}_{3 \mathrm{~T}}$ & $0.993^{*}$ & 34.792 & 0.985 & $1210.492^{*}$ \\
\hline NER $_{4 \mathrm{~T}}$ & $0.990^{*}$ & 29.409 & 0.978 & $864.910^{*}$ \\
\hline \multirow{2}{*}{ Determinants } & Dependent Variable: POPGR & \multicolumn{3}{|l}{} \\
\cline { 2 - 5 } & Standardised $\beta$ & t-value & Adjusted $\mathrm{r}^{2}$ & F-value \\
\hline $\mathrm{NER}_{1 \mathrm{~T}}$ & -0.429 & -2.016 & 0.139 & 4.064 \\
\hline $\mathrm{NER}_{2 \mathrm{~T}}$ & $-0.771^{*}$ & -5.141 & 0.572 & $26.434^{*}$ \\
\hline $\mathrm{NER}_{3 \mathrm{~T}}$ & $-0.721^{*}$ & -4.410 & 0.493 & $19.449^{*}$ \\
\hline $\mathrm{NER}_{4 \mathrm{~T}}$ & $-0.729^{*}$ & -4.520 & 0.506 & $20.431^{*}$ \\
\hline
\end{tabular}

Number of Observations: $20 \quad$ *: Significant at 1 per cent level.

\section{Summary of Findings and Conclusions}

The main findings of this paper can be summarized as below:

1. Female education at all levels has been found to be highly significant in lowering infant mortality. This shows that educated mothers remain aware of the various health programmes of the State (e.g. National Immunization Programme) and hence, are expected to act positively to do away with various causes of infant mortality. As expected, per capita income is negatively associated with infant mortality.

2. Male and female life expectancy at birth and at specific ages have been found to be positively related with enrolment at different educational levels. This shows that education enables individuals to gain knowledge about nutrition that lowers mortality rates and increases life expectancy.

3. The indicators of enrolment growth for different age groups and education levels are inversely related with fertility rates. It shows that increased female education at all the stages (i.e. primary, elementary, secondary and for all education levels put together) consistently lower fertility rates. This finding of our study is in line with the research conducted in different parts of the world which shows that women with more education make a better transition to adulthood and have smaller, and healthier families. They usually have their first sexual experience later, marry later, prefer smaller families and are likely to use contraceptives as compared to their less educated counterparts. Further, education provides economic incentives to women to have fewer children so that they can enter job markets.

4. Our regression results show positive relationship between the progress of education at different stages and the gender disparity in infant mortality. This unwanted situation may be attributed to social, cultural and economic rather than health, education and medical factors. The correlations of sex ratios (for total as well as for child population) with the expansion of education at different stages are negative and, by and large, statistically significant. This unfavorable situation can also be attributed to socio-economic and cultural aspects of the society.

5. The relationship of educational progress with population increase in absolute figures is positive and statistically significant at 0.01 level. This is not unexpected as the effects of education on population growth follow directly from infant mortality, longevity, and fertility effects. As educational growth improves health, increases longevity, reduces infant mortality and fertility rate, hence the net population growth in absolute terms may tend to increase with educational progress. However, the rate of population growth has slowed with educational progress. 


\section{Implications}

Significance of education in the development process has been well recognized by the educational planners, economists and development planners the world over. This study has empirically examined the association of education and social development for Punjab during the last two or three decades. Having confirmed the contribution of education to development, this study put forward the following implications for the state:

1. The State should first treat education as an important investment activity like any other physical capital investment activity and not as consumption expenditure. Education should be taken as an important input into the development process.

2. Socio-economic development of the state is closely integrated with education. The intersectoral links between education, economic growth, health, nutrition, population, poverty, etc. should be duly recognized. For satisfactory progress in that direction, development of education should include both quantitative expansion and qualitative improvement.

3. Education of women should be given at least as much importance as is given to that of men. Women's education significantly influences family welfare and health, including improvement in child survival, and population growth, through its impact on fertility and family planning practices. Still one of the main hindrances that come in the way of rural female education is availability of professional education and vocational training in distant institutions usually situated in urban areas. As they are not allowed to go there due to transportation problems and insecurity, government should set up these institutions in the rural areas.

\section{References}

Appiah, E. N. and McMahon, W. W. (2002). The Social Outcome of Education and Feedbacks on Growth in Africa. The Journal of Development Studies, 38 (4), 27-68.

Atal, Y. (2007). On Education and Development: Essays on the Sociology of Education. India: Rawat Publications.

Becker, G. S. (1975, 2nd ed.). Human Capital. New York: National Bureau of Economic Research.

Brar, J. S. (2002). Basic Education, Health Care and Economic Growth in Punjab: Achievements, Gaps and Imbalances. Man \& Development (March), XXIV (1), 51-63.

Cochrane, S. H. (1979). Fertility and Education: What Do We Really Know? Baltimore, MD: Johns Hopkins University Press.

Cochrane, S., O’ Hara, D.J. and Leslie, J. (1980). The Effects of Education on Health. (World Bank Staff Working Paper No. 105). Washington, DC: World Bank.

Education Commission (1966): Education and National Development: Report of the Education Commission 1964-66, Government of India, Ministry of Education [Reprint by the National Council of Educational Research and Training, March 1971], New Delhi.

Frank, J. and Mustard, J. F. (1994). The Determinants of Health from a Historical Perspective. Daedalus: Proceedings of the American Academy of Arts and Sciences, 123 (4), 675-82.

Grossman, M. and Kaestner, Robert (1997). Effects of Education on Health. In Behrman and Stacey (Eds). The Social Benefits of Education. Ann Arbor, MI: University of Michigan Press.

Gupta, M. D. (1990). Death Clustering, Mothers' Education and the Determinants of Child Mortality in Rural Punjab, India. Population Studies, 44, 489-505. 
Haveman, R. H. and Wolfe, B. L. (1984). Schooling and Well-being: The Role of Nonmarket Effects. Journal of Human Resources. 19 (3) (Summer), 377-407.

Jerath, A. (2005, December 5). Female foeticide high among educated mothers: Study. Tribune (Jalandhar); p.3.

Mathur, A. and Mamgain, R. P. (2002). Technical Skills, Education and Economic Development in India. The Indian Journal of Labour Economics, 45 (4), 1015-1046.

Moore, K., Meyers, D., Morrison, D.; Nord, C., Brown, B. and Edmonston, B. (1993). Age at First Childbirth Later Poverty. Journal of Research Adolescence, 3 (4).

Natarajan, S. (1990). Introduction to Economics of Education. New Delhi: Sterling Publishers Pvt. Ltd.

Olaniyan. D. A and Okemakinde. T. (2008). Human Capital Theory: Implications for Educational Development. European Journal of Scientific Research, ISSN 1450-216X, 24 (2),.157-162. (http://www.eurojournals.com/ejsr.htm.

Rao, D. P. (2004). Women's Education and Maternal and Infant Mortality in India: An Empirical Analysis. IASSI Quarterly, 22 (4), 107-122.

Sarkaria, M. S. (2002). Social Change Through Women Education in India. In Women as Resource Manager (pp. 178-190). Compilation of papers presented in the State Level Seminar on "Women as Resource Manager" organized by DAV College of Education, Amritsar on 29-30 October.

Schultz, T. P. (1993). Returns to women's education. Chapter 2 in E. King and M. Hill (Eds.), Women's education in developing countries. Washington D.C.: Johns Hopkins Press for the World Bank.

Tilak, J. B.G. (2001). Education and Development: Lessons from Asian Experience. Indian Social Science Review, 3 (2), 219-266.

United Nations (1995). Women's Education and Fertility Behaviour. New York: ST/ESA/SER.R/137 Population Division.

Vaizey, John (1962). Economics of Education. London: Faber and Faber.

Zaidi, S. M. I. A. (1997). Indicators of Educational Development. In N. V. Varghese (Ed.), Modules on District Planning in Education. Module 6. New Delhi: National Institute of Educational Planning and administration. 


\section{Appendix -I}

\begin{tabular}{|c|c|c|c|}
\hline Sn & Abbreviation & Variables & Data Source \\
\hline 1 & IMR & Infant Mortality Rate & $\begin{array}{l}\text { Registrar General of India, } \\
\text { Compendium of India's Fertility \& } \\
\text { Mortality indicators based on } \\
\text { sample registration system, New } \\
\text { Delhi \& various other volumes \& } \\
\text { websites }\end{array}$ \\
\hline 2 & LEXP & Life Expectancy & $\begin{array}{l}\text { Ageing Population of India: an } \\
\text { analysis of Census data, Registrar } \\
\text { General of India \& websites }\end{array}$ \\
\hline 3 & TFR & Total Fertility Rate & $\begin{array}{l}\text { Sample Registration system (SRS), } \\
\text { Registrar General of India,. } \\
\text { Various volumes \& websites }\end{array}$ \\
\hline 4 & $\mathbf{L E X P}_{0 \mathrm{M}}$ & Male Life Expectancy (in years) at birth & Same as above \\
\hline 5 & $\mathbf{L E X P}_{\mathbf{0 F}}$ & Female Life Expectancy (in years) at birth & Same as above \\
\hline 6 & LEXP $_{60 M}$ & Male Life Expectancy (in years) at ages 60 & Same as above \\
\hline 7 & LEXP $_{60 F}$ & Female Life Expectancy (in years) at ages 60 & Same as above \\
\hline 8 & POV & Poverty: Population below poverty line & Various Volumes of NSSO \\
\hline 9 & $\mathbf{N E R}_{1 \mathrm{~T}}$ & Net Enrolment Rates, Primary, Total (6-11) & $\begin{array}{l}\text { Director Public Instruction, } \\
\text { Schools, Punjab; cf Economic } \\
\text { Survey of Punjab }\end{array}$ \\
\hline 10 & $\mathbf{N E R}_{2 \mathrm{~T}}$ & $\begin{array}{l}\text { Net Enrolment Rates, Elementary, Total (11- } \\
14)\end{array}$ & Same as above \\
\hline 11 & $\mathbf{N E R}_{3 T}$ & $\begin{array}{l}\text { Net Enrolment Rates, Secondary, Total (14- } \\
18 \text { ) }\end{array}$ & Same as above \\
\hline 12 & $\mathbf{N E R}_{4 \mathrm{~T}}$ & Net Enrolment Rates, Overall, Total (6-18) & Same as above \\
\hline 13 & NER $_{1 F}$ & Net Enrolment Rates, Primary, Female (6-11) & Same as above \\
\hline 14 & $\mathbf{N E R}_{2 \mathrm{~F}}$ & $\begin{array}{l}\text { Net Enrolment Rates, Secondary, Female (11- } \\
14)\end{array}$ & Same as above \\
\hline 15 & $\mathbf{N E R}_{3 \mathrm{~F}}$ & $\begin{array}{l}\text { Net Enrolment Rates, Secondary, Female (14- } \\
18 \text { ) }\end{array}$ & Same as above \\
\hline 16 & $\mathbf{N E R}_{4 \mathrm{~F}}$ & $\begin{array}{l}\text { Net Enrolment Rates, Secondary, Female (6- } \\
18 \text { ) }\end{array}$ & Same as above \\
\hline 17 & GNDSIMR & Gender Disparity $(\mathrm{f} / \mathrm{m})$ in infant mortality & $\begin{array}{l}\text { Sample Registration System (SRS) } \\
\text { Registrar General, India. Various } \\
\text { Volumes. Based on sex specific } \\
\text { moving averages }\end{array}$ \\
\hline 18 & $\begin{array}{l}\text { GNDSSRAL } \\
\text { AG }\end{array}$ & $\begin{array}{l}\text { Gender Disparity in Sex Ratios for all ages, } \\
\text { Sex Ratio defined as number of females per } \\
1,000 \text { males }\end{array}$ & Census of India, India and Punjab \\
\hline 19 & GNDSSR $_{0-6}$ & $\begin{array}{l}\text { Gender Disparity in Sex Ratios for children of } \\
0-6 \text { age group }\end{array}$ & Same as above \\
\hline 20 & POP & Population increase in absolute figures & $\begin{array}{l}\text { Regional Monitoring Service, } \\
\text { CMIE, and Census of India and } \\
\text { Punjab }\end{array}$ \\
\hline 21 & POPGR & Annual growth rates of population & Same as above \\
\hline 22 & $\mathbf{E X P}_{\text {Gen }}$ & Expenditure on general education & Same as above \\
\hline 23 & $\mathbf{E X P}_{\mathrm{Gen} \%}$ & Percentage expenditure on general education & Same as above \\
\hline 24 & $\mathbf{E X P}_{\text {Tech }}$ & Expenditure on technical education & Same as above \\
\hline 25 & $\mathbf{E X P}_{\text {Tech\% }}$ & Percentage expenditure on technical education & Same as above \\
\hline
\end{tabular}

